\title{
In Vitro Anti-Cholinesterase and Antioxidant Activity of Extracts of Moringa oleifera Plants from Rivers State, Niger Delta, Nigeria
}

\author{
Lucky Legbosi Nwidu 1,*(D), Ekramy Elmorsy ${ }^{2}$, Jonah Sydney Aprioku ${ }^{1}$, Iyeopu Siminialayi ${ }^{3}$ \\ and Wayne Grant Carter ${ }^{4}$ \\ 1 Department of Experimental Pharmacology and Toxicology, Faculty of Pharmaceutical Sciences, \\ University of Port Harcourt, Port Harcourt PMB 5323, Rivers State, Nigeria; sydaprio@yahoo.com \\ 2 Department of Forensic Medicine and Clinical Toxicology, Faculty of Medicine, Mansoura University, \\ Mansoura 35516, Egypt; elkramy_elmorsy@yahoo.com \\ 3 Department of Pharmacology, Faculty of Basic Medical Sciences, University of Port Harcourt, \\ Port Harcourt PMB 5323, Rivers State, Nigeria; siminialayi@yahoo.com \\ 4 School of Medicine, University of Nottingham, Royal Derby Hospital Centre, Derby DE22 3DT, UK; \\ wayne.carter@nottingham.ac.uk \\ * Correspondence: menelucky@yahoo.com
}

Received: 15 May 2018; Accepted: 3 July 2018; Published: 5 July 2018

\begin{abstract}
This study evaluated Moringa oleifera extracts from two locations in Niger Delta for in vitro anti-cholinesterase and antioxidant activities. Methanolic, aqueous and ethanolic extracts of Moringa oleifera were evaluated for inhibition of acetylcholinesterase (AChE) activity, antioxidant properties, and total phenolic and flavonoid contents using standard procedures. M. oleifera extracts possessed significant and concentration dependent AChE inhibitory activity for methanolic, aqueous, and ethanolic extracts. For the most potent extracts, the percentage $\mathrm{AChE}$ inhibition $/ \mathrm{IC}_{50}(\mu \mathrm{g} / \mathrm{mL})$ values were Moringa oleifera root methanolic extracts (MORME): 80\%/0.00845; Moringa oleifera root ethanolic extract 1 (MOREE1): 90\%/0.0563; Moringa oleifera root ethanolic extract 2 (MOREE2): $\sim 70 \% / 0.00175$; and Moringa oleifera bark ethanolic extract (MOBEE): 70\%/0.0173. The descending order of AChE inhibitory potency of plant parts were: root $>$ bark $>$ leaf $>$ flowers $>$ seed. All M. oleifera methanolic extracts at a concentration of $1000 \mu \mathrm{g} / \mathrm{mL}$ displayed significant $(p<0.05-0.001)$ DPPH radical scavenging activity, with values of $\sim 20-50 \%$ of that of ascorbic acid. The total phenolic content and total flavonoid content (TPC/TFC) of MORME, Moringa Oju bark methanolic extract (MOBME), MOREE1, MOREE2 and Moringa leaf ethanolic leaf extract (MLEE) were (287/254), (212/113), (223/185), (203/343) and (201/102) mg gallic acid equivalents/g and quercetin equivalents/g, respectively. There was an inverse correlation between plant extract $\mathrm{AChE}$ inhibition and total phenolic $(p<0.0001)$ and total flavonoid contents $(p<0.0012)$. In summary, this study revealed 5 of 19 extracts of $M$. oleifera that have potent in vitro anti-cholinesterase and antioxidant activities.
\end{abstract}

Keywords: Moringa oleifera; anti-cholinesterases; DPPH radical scavenging; antioxidant; oxidative stress; Alzheimer's disease

\section{Introduction}

Alzheimer's disease (AD) is the most prevalent neurodegenerative disease and is associated with progressive and irreversible loss of cognitive abilities, memory loss, cognitive impairment, emotional dysfunction, and ultimately death [1]. AD accounts for $50-70 \%$ of all cases of dementias [2,3], and for which dementia such as $\mathrm{AD}$ is a major cause of disability in the elderly. The epidemic scale of dementia poses one of the major challenges on global public health systems and associated financial burden 
with the social care needed. In 2015, an estimate of the number of people living with dementia was 46.8 million, with an associated economic burden of 818 billion US dollars, with numbers expected to grow year on year $[3,4]$. The financial burden, coupled to the social stigma associated with the loss of cognitive abilities and dependency on others, imposes considerable psychological distress in patients as well as their families [5].

$\mathrm{AD}$ is characterized by the formation of senile plaques, composed mainly of amyloid $\beta(\mathrm{A} \beta)$, and neurofibrillary tangles (NFTs), composed of tau protein, in the hippocampus and cerebral cortex of afflicted humans $[6,7]$. These protein aggregates $(\mathrm{A} \beta$ and tau proteins) provoke neuronal damage and synaptic dysfunction $[8,9]$, hence the inhibition of their formation remains a potential therapeutic approach for the treatment of $\mathrm{AD}[10]$.

These abnormal protein accumulations also underpin neuro-inflammatory responses, neuronal toxicity, cell death, and cerebral atrophy [11]. The pathogenesis of AD is complex and multi-faceted and includes oxidative stress [12], inflammation [13], mitochondrial damage and/or dysfunction [14] and a cholinergic signaling deficit [15]. Attempts to preclude the cholinergic deficit have triggered the development of cholinomimetics and acetylcholinesterase inhibitors to maintain cholinergic transmission in the AD brain. Drugs such as tacrine, rivastigmine, donepezil, huperizine A and physostigmine (eserine) have been employed to treat patients with mild to moderate AD. However, these drugs only alleviate cholinergic symptoms, and were not designed to address other mechanistic pathways involved in $\mathrm{AD}$ disease progression. In fact, oxidative damage has been suggested to be a primary event in AD [16]. Indeed, protein, lipid, and DNA oxidation have been observed in brain tissues of AD Patients [17].

To preclude the risk associated with synthetic antioxidants, the utilization of natural antioxidants has been advocated $[18,19]$. Since natural antioxidants are an essential component of health and might prevent or delay cell damage [20], they have been exploited as potential leads for the development of novel AD drugs [21,22]. Furthermore, the neuroprotective effects of natural antioxidants and nootropics [23], such as Ginkgo biloba [24] and Bacopa monnieri [25] have attracted considerable attention in the management of $\mathrm{AD}[26]$.

Moringa oleifera belongs to the family Moringaceae. It is commonly known as horse radish tree or drumstick tree. It is a small-medium sized tree, 10-15 m high; widely cultivated in East and Southeast Asia, Polynesia, and the West Indies. It is also indigenous to North West India and many countries in Africa, South East Asia, Arabia, the Pacific, South America, and the Caribbean Islands. It is a widely cultivated tree, and considered a multi-purpose plant [27]. Although 12 varieties of Moringa species exist, it is likely that $M$. oleifera is the most widely known [27]. Almost all the plant parts: root, bark, gum, leaf, fruit (pods), flowers, seed and seed oil have been marketed as herbal therapies for various ailments in the Niger Delta of Nigeria. Diseases treated include inflammatory and infectious diseases, as well as cardiovascular, gastrointestinal, and hematological and hepatorenal disorders [28]. In Thailand, the tender pods, fruits and leaves of M. oleifera have been consumed as vegetables for over 100 years, while the hot water extract of the dried roots has been taken orally as a cardiotonic and a stimulant against fainting [29]. The potential therapeutic values against cancer, diabetes, rheumatoid arthritis, and other diseases have earned this plant the name of "wonder tree" in Thailand [30].

Extracts from $M$. oleifera display multiple pharmacological activities, including anti-inflammatory [31-34], antibacterial [35], antioxidant [36], anti-cancer [37], hepatoprotective [38,39] and neuroprotective [40-42] activities. The leaves and fruits also possess hypocholesterolaemic activity in Wistar rats [43] and rabbits [44].

A number of phytochemicals are present within, and obtained from, the Moringa plant, and these may contribute to its broad biological activity. For example, tannins, saponins, alkaloids, flavonoids, phenols and glycosides are resident within the leaves [45]; tannins, steroids, flavonoids, alkaloids, glycosides, quercetin and terpenoids within the flowers [46]; gallic acid, catechins, epicatechin, ferulic acid, vanillin, caffeic acid, protocatecuic acid, cinnamic acid, phytosterol, quercetin, glycosides and phenols within the seeds [47]; procyanidins, aurantiamide acetate, 3-dibenzylurea, quercetin glycoside, 
rhamnoglucoside quercetin and chlorogenic acid within the roots; and, procyanidin, sterols, triterpenoids, glycosides, tannins, alkaloids, $\beta$-sitosterol and octacosanoic acid from the stem bark [48]. Hence M. oleiferia has been extensively studied because of its enormous potentials as a source of nutraceuticals of medicinal value [49-51]. The plants from various regions of the world such as India [28], Thailand [30], Jamaica [52] and Pakistan [53] have been pharmacologically characterized, including the in vitro evaluation of antioxidant activity [54].

However, we have focused our attention to the M. oleiferia plant found in the Niger Delta of Nigeria, a region impacted by enormous exploration and exploitation of petroleum. Our research goal was to characterize the pharmacological activity of different parts of the M. oleifera plant, and from two different localities, and to focus upon its potential in vitro anti-cholinesterase and antioxidant activities.

\section{Materials and Method}

\subsection{Plant Materials Collection and Identification}

Moringa oleifera parts (leaves, seeds, roots, flowers and bark) were collected in March 2015. The plant was authenticated by Mr. Okeke Chimezie, a botanist of the Department of Plant Science and Biotechnology, University of Port-Harcourt, Nigeria. Two garden specimens from two different locations in Rivers state, Nigeria: a coastland (No. 5, Abuloma Road, in Port Harcourt), and Hinterland (Okpaka's Compound, Elele Alumini, Port-Harcourt), Nigeria were used for this study. A plant voucher number (UPH/P/60) was deposited in the University's herbarium. The samples were air-dried for seven days and then powdered using an electrical blender and grinder, S-742 (Saisho, Nanjing, China).

\subsection{Preparation of Methanolic, Ethanolic and Aqueous Extracts of Moringa oleifera}

Moringa oleifera plants were collected and powdered, and samples weighed separately, before maceration in methanol or ethanol for 72 hours, as follows: leaf ( $300 \mathrm{~g}$ in $1500 \mathrm{~mL}$ of solvent), bark ( $250 \mathrm{~g}$ in $800 \mathrm{~mL}$ of solvent), root (250 $\mathrm{g}$ in $800 \mathrm{~mL}$ of solvent), seed (120 $\mathrm{g}$ in $300 \mathrm{~mL}$ of solvent), flower (120 g in $400 \mathrm{~mL}$ of solvent), respectively. Macerated samples were shaken 3 times daily to assist solvation. Solutions were then filtered using double-layered gauze. Filtrates were dried in vacuo at $40-50{ }^{\circ} \mathrm{C}$ on a water bath to obtain the methanolic or ethanolic dry extracts. Single sample extracts were weighed, and the percentage yield for each sample recorded.

For the aqueous extract, powdered samples of Moringa oleifera were weighed and extracted by a soxlet extraction method using distilled water. At the end of extraction, aqueous extract solution was dried in vacuo to obtain dry aqueous extracts. Single sample extracts were weighed, and the percentage yield for each sample recorded.

Collectively, we have prepared 19 extracts ( 8 methanolic, 3 aqueous, and 8 ethanolic). The higher number of methanolic and ethanolic extracts reflected the common usage of these solvents in ethnomedicine.

\subsection{Chemicals}

Acetylthiocholine iodide (ATCI), ascorbic acid, bovine serum albumin (BSA), 2,2-Diphenyl-1picrylhydrazyl (DPPH), 5,5-dithiobis (2-nitrobenzoic acid) (DTNB), Folin-Ciocalteau Reagent (FCR), gallic acid, physostigmine, and $\beta$-tocopherol were all purchased from Sigma Aldrich (Irvine, UK).

\subsection{Animals}

To provide a source of mammalian acetylcholinesterase (AChE) enzyme, rat brain homogenates were used. Rats were male F344 strain, weight $200-230$ g, as reported previously [55-57]. The use of these animals received approval from the University of Nottingham Local Ethical Review Committee (2008) (study reference CHE 10), with procedures performed in accordance with the Animals Scientific Procedures Act (UK) 1986. 


\subsection{Assay for Acetylcholinesterase Inhibitory Activity}

AChE activity was measured within a 96-well microtitre plate based on the Ellman [58] method. Forty $\mu \mathrm{L}$ of plant extracts at concentrations of $200,20,2,0.2$ and $0.02 \mu \mathrm{g} / \mathrm{mL}$ were mixed with $50 \mu \mathrm{L}$ of $3 \mathrm{mM}$ DTNB, $50 \mu \mathrm{L}$ of AChE $(1 \mathrm{mg} / \mathrm{mL}$, Sigma, C3389, Irvine, UK) or rat brain homogenate (prepared at $10 \%(w / v)$ according to references [55,56], and $35 \mu \mathrm{L}$ of $50 \mathrm{mM}$ Tris- $\mathrm{HCl}(\mathrm{pH} 8.0)$ containing $0.1 \% \mathrm{BSA}$, and samples incubated for $5 \mathrm{~min}$ at $37^{\circ} \mathrm{C}$. The reaction was initiated by addition of $25 \mu \mathrm{L}$ of $15 \mathrm{mM}$ ATCI resulting in the production of a 5-thio-2-nitrobenzoate anion read at $412 \mathrm{~nm}$ every $5 \mathrm{~s}$ for $10 \mathrm{~min}$ using a Spectramax microplate reader (ThermoFisher, Stafford, UK).

To establish suitable optical density changes and linearity of signal, a 1:10 dilution of rat brain homogenate (in $10 \mathrm{mM}$ Tris- $\mathrm{HCl} \mathrm{pH}$ 8.0) was used for AChE measurements. This rat brain positive control for AChE activity was inhibited in a dose-dependent manner by either eserine or organophosphorus pesticides [57].

\subsection{Determination of 2,2-Diphenyl-1-picrylhydrazyl (DPPH) Radical Scavenging Effects}

A DPPH radical scavenging assay was employed to determine, by a spectroscopic method, relative plant antioxidant ability. Anti-radical activities of plant extracts were estimated, according to the method of Nwidu et al. [57]. Stock solutions of extracts $(5 \mathrm{mg} / \mathrm{mL})$ were prepared and diluted to final concentrations of 200,100,50, 25, 12.5 and $6.25 \mu \mathrm{g} / \mathrm{mL}$ in ethanol. One hundred and $60 \mu \mathrm{L}$ of $0.1 \mathrm{mM}$ DPPH in ethanol solution was added to $20 \mu \mathrm{L}$ of the extracts or standard, and then mixed with $20 \mu \mathrm{L}$ of $\mathrm{H}_{2} \mathrm{O}$. $\beta$-tocopherol (as a control solution) over the concentration range of $1.56,0.780 .39,0.195$, and $0.0975 \mathrm{mg} / \mathrm{mL}$ was assayed under similar conditions. The mixtures were incubated at $37^{\circ} \mathrm{C}$ for $40 \mathrm{~min}$ in the dark. Sample absorbance was read at $517 \mathrm{~nm}$, as described in Nwidu et al. [57].

\subsection{Reducing Power Capacity Assessment}

The reducing capacity of plant extracts were estimated based upon their ability to reduce ferric ions $\left(\mathrm{Fe}^{3+}\right)$ to ferrous ions $\left(\mathrm{Fe}^{2+}\right)$. The concentrations of the plant extracts ranged from 6.25 to $50 \mu \mathrm{g} / \mathrm{mL}$. Four $\mu \mathrm{L}$ of $5 \mathrm{mg} / \mathrm{mL}$ of each plant extract was mixed with $400 \mu \mathrm{L}$ of phosphate buffer $(0.2 \mathrm{M}$ dibasic sodium phosphate and 0.2 M monobasic sodium phosphate buffer, $\mathrm{pH} 7.4$ ) and $250 \mu \mathrm{L}$ of $1 \%$ potassium ferricyanide added, and then the mixture was incubated at $50{ }^{\circ} \mathrm{C}$ for $20 \mathrm{~min}$. Then, $250 \mu \mathrm{L}$ of $10 \%$ trichloroacetic acid was added, and the samples centrifuged at $3000 \mathrm{rpm}$ for $10 \mathrm{~min}$. One hundred $\mu \mathrm{L}$ of the supernatant was mixed with $100 \mu \mathrm{L}$ of water followed by the addition of $20 \mu \mathrm{L}$ of freshly prepared ferric chloride solution. Samples were then read at $700 \mathrm{~nm}$, according to Nwidu et al. [57]. L-Ascorbic acid was employed as a positive control antioxidant.

\subsection{Determination of Total Phenolic Content}

Quantitation of total phenolics was determined spectrophotometrically at $760 \mathrm{~nm}$, based on a colorimetric measurement (Folin-Ciocalteu Reagent (FCR) method) as described in a previous publication [57]. Plant extracts were assessed across the concentration range of $1-100 \mu \mathrm{g} / \mathrm{mL}$. Twenty $\mu \mathrm{L}$ of plant extract was added to $90 \mu \mathrm{L}$ of water, followed by addition of $30 \mu \mathrm{L}$ of FCR and then the samples were shaken vigorously in a plate reader. Within eight minutes, $60 \mu \mathrm{L}$ of $7.5 \%$ $\mathrm{Na}_{2} \mathrm{CO}_{3}$ solution was added, and the samples incubated at $40{ }^{\circ} \mathrm{C}$ on a shaking incubator, before reading at $760 \mathrm{~nm}$ in a spectrophotometer. Gallic acid over the concentration range of $0.1-0.5 \mathrm{mg} / \mathrm{mL}$ was processed in a similar fashion to provide a standard curve.

\subsection{Determination of Total Flavonoid Content}

Total flavonoid contents of the plant extracts was also determined according to the previously published method [57]. Quercetin was used as a reference compound. Twenty $\mu \mathrm{L}$ of plant extract $(5 \mathrm{mg} / \mathrm{mL}$ ) in ethanol was mixed with $200 \mu \mathrm{L}$ of $10 \%$ aluminum chloride solution and $1 \mathrm{M}$ potassium 
acetate. The mixture was incubated for $30 \mathrm{~min}$ at room temperature, and then read at $415 \mathrm{~nm}$, according to Nwidu et al. [57].

\subsection{Statistical Analysis}

Results are expressed as means \pm SD. The concentration of plant extract producing $50 \%$ inhibition $\left(\mathrm{IC}_{50}\right)$ was calculated using non-linear regression analysis. A one-way ANOVA with Dunn's multiple comparisons post-test was used to compare group data sets. A Spearman rank-order correlation coefficient was used to assess the relationship between total phenolic content, total flavonoid content, antioxidant content, and inhibition of AChE activity. Statistical analyses were performed using GraphPad Prism (Version 5.3) for Windows (GraphPad Software, Inc., San Diego, CA, USA, www. graphpad.com), with a $p$ value of $<0.05$ considered significant.

\section{Results}

\subsection{Moringa Oleifera Acetylcholinesterase Inhibitory Activity}

M. oleifera extracts possessed significant and concentration dependent AChE inhibitory activity for methanolic, aqueous, and ethanolic extracts (Figure 1 and Table 1). For the most potent extracts, the percentage $\mathrm{AChE}$ inhibition/ $\mathrm{IC}_{50}(\mu \mathrm{g} / \mathrm{mL})$ values were Moringa oleifera root methanolic extracts (MORME): 80\%/0.00845; Moringa oleifera root ethanolic extract 1 (MOREE1): 90\%/0.0563; Moringa oleifera root ethanolic extract 2 (MOREE2): 70\%/0.00175; and, Moringa oleifera bark ethanolic extract (MOBEE): $\sim 70 \% / 0.0173$. The descending order of AChE inhibitory potency of plant parts were: root $>$ bark $>$ leaf $>$ flowers $>$ seed.

The descending order of AChE inhibitory potency for the M. oleifera methanolic extracts was MORME > MOSME (c) > MOBME > MOLME > MOFME > MOSME > MOSME (h) > MOFPME; for M. oleifera aqueous extracts was: MOBAE > MORAE > MOFAE; and for M. oleifera ethanolic extracts: MOREER2 > MOBEE > MOREE1 > MOLEE > MOSEE2 > MOFEE2 > MOFEE1 > MOSEE1 (refer to Table 1).

\subsection{Moringa Oleifera DPPH Radical Scavenging Activity}

Methanolic, aqueous and ethanolic extracts of M. oleifera displayed DPPH radical scavenging activities in concentrations dependent manner, although for the aqueous fractions relatively low levels of radical scavenging was apparent (Figure 2 and Table 1). At a concentration of $1000 \mu \mathrm{g} / \mathrm{mL}$, all $M$. oleifera methanolic extracts exhibited significant $(p<0.05-0.001)$ radical scavenging activity from $\sim 20-50 \%$ of that of ascorbic acid (set at 100\%) (Figure 2). The descending order of radical scavenging for the methanolic extracts was: MOLME $>$ MOFPME $>$ MOSME $(\mathrm{h})>$ MOFME $>$ MOSME $>$ MOSME (c) > MOBME > MORME; for the aqueous extracts: MOBAE > MOFAE > MORAE; and ethanolic extracts: MOREE1 > MOSEE2 > MOREE2 > MOLEE > MOBEE > MOFEE1 = MOFEE2 > MOSEE1 (Table 1).

When considering the location of the plants, the MOREE1 from the coastland had a DPPH radical scavenging ability of $\sim 70 \% / \mathrm{IC}_{50}$ of $0.1176 \times 10^{-3} \mathrm{mg} / \mathrm{mL}$, whereas MOREE2 from the hinterland had a similar scavenging activity of $\sim 70 \%$, but with a higher $\mathrm{IC}_{50}$ of $0.4097 \times 10^{-3} \mathrm{mg} / \mathrm{mL}$. 

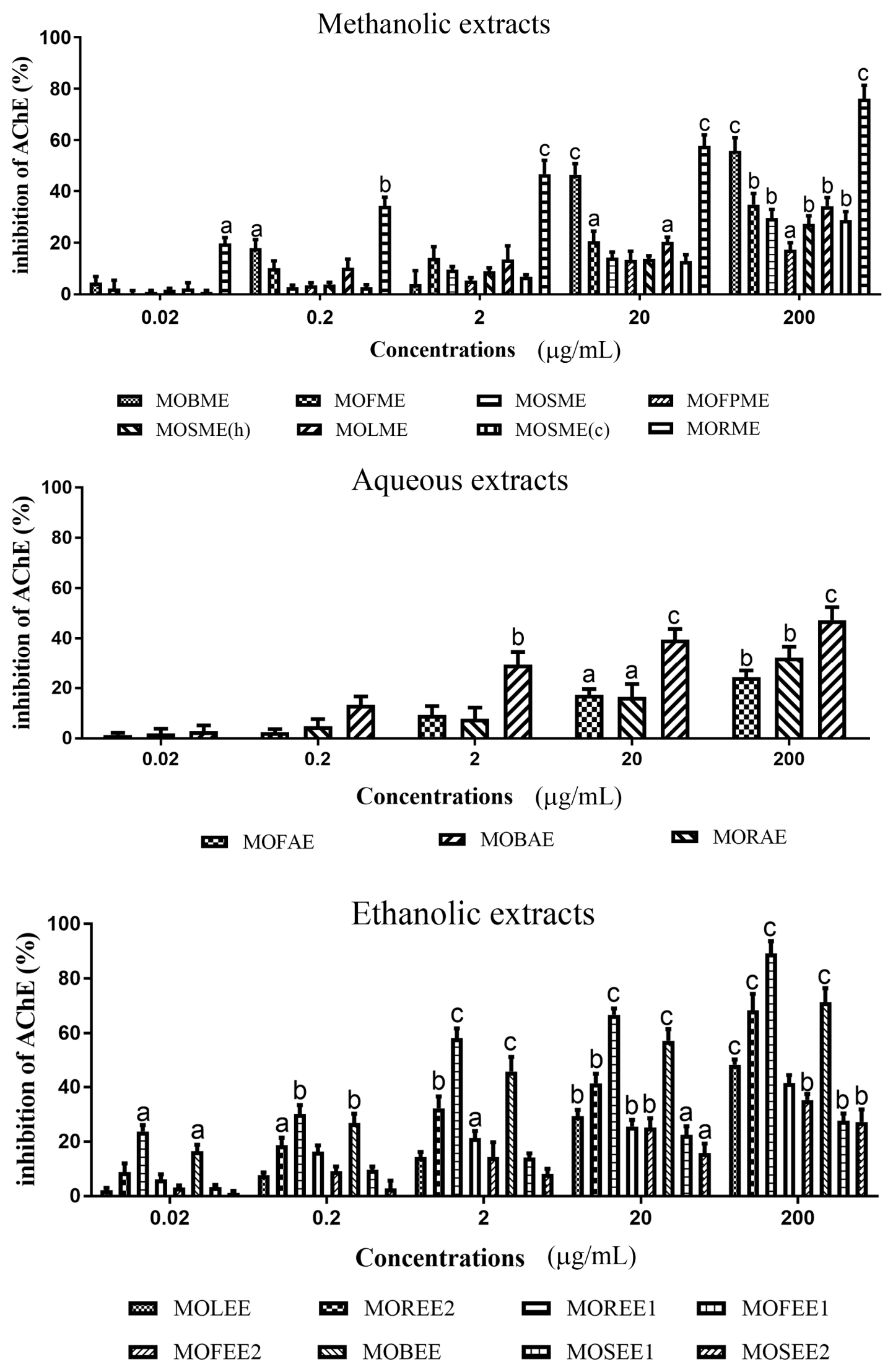

Figure 1. Acetylcholinesterase (AChE) inhibitory activity of plant extracts from Moringa oleifera. Plant extract inhibition of AChE was measured using a modified Ellman assay, with percentage inhibition of AChE calculated relative to eserine. The histograms presented are means \pm SEM for at least three replicate assays at each extract concentration. a: $p<0.05$. b: $p<0.01$. c: $p<0.001$. 
Table 1. Percentage yield, AChE inhibitory, and 2,2-Diphenyl-1-picrylhydrazyl (DPPH) radical scavenging potency of Moringa oleifera methanolic, aqueous and ethanolic extracts.

\begin{tabular}{|c|c|c|c|}
\hline \multirow{2}{*}{ Moringa oleifera Extracts } & \multirow{2}{*}{ Yield (\%) } & \multicolumn{2}{|r|}{$\mathrm{IC}_{50}$ Concentrations $(\mathrm{mg} / \mathrm{mL})$} \\
\hline & & AChE & DPPH Radical Scavenging $\left(\times 10^{-3}\right)$ \\
\hline \multicolumn{4}{|l|}{ Methanolic } \\
\hline MOBME & 2.67 & 0.1740 & 0.1419 \\
\hline MOFME & 8.88 & 0.2750 & 0.04767 \\
\hline MOSME & 3.44 & 0.3425 & 0.04902 \\
\hline MOFPME & 14.71 & 0.4335 & 0.02579 \\
\hline MOSME (h) & 6.83 & 0.3863 & 0.04561 \\
\hline MOLME & 4.78 & 0.2615 & 0.02517 \\
\hline MOSME (c) & 3.68 & 0.08723 & 0.08723 \\
\hline MORME & 9.84 & 0.00845 & 0.3148 \\
\hline \multicolumn{4}{|l|}{ Aqueous } \\
\hline MOFAE & 39.1 & 0.3784 & 0.1313 \\
\hline MOBAE & 26.2 & 0.2185 & 0.08298 \\
\hline MORAE & 14.3 & 0.2764 & 0.1574 \\
\hline \multicolumn{4}{|l|}{ Ethanolic } \\
\hline MOLEE & 5.3 & 0.2105 & 0.4638 \\
\hline MOREE2 & 1.1 & 0.00175 & 0.4097 \\
\hline MOREE1 & 6.3 & 0.0563 & 0.1176 \\
\hline MOFEE1 & 14.4 & 0.2756 & 0.6819 \\
\hline MOFEE2 & 3.1 & 0.2654 & 0.6819 \\
\hline MOBEE & 10.2 & 0.0173 & 0.6709 \\
\hline MOSEE1 & 7.1 & 0.2864 & 3.168 \\
\hline MOSEE2 & 10.3 & 0.2464 & 0.1653 \\
\hline
\end{tabular}

Methanolic extracts: MOBME, Moringa oleifera bark methanolic extract; MOFME, Moringa oleifera flower methanolic extract; MOSME, Moringa oleifera stembark methanolic extract; MOFPME, Moringa oleifera food powder methanolic extract; MOSME (h), Moringa oleifera stalk methanolic extract (hot); MOLME, Moringa oleifera leaf methanolic extract; MOSME (c), Moringa oleifera stalk methanolic extract (cold); MORME, Moringa oleifera root methanolic extract. Aqueous extracts: MORAE, Moringa oleifera root aqueous extract; MOFAE, Moringa oleifera flower aqueous extract; MOBAE, Moringa oleifera bark aqueous extract. Ethanolic extracts: MOLEE, Moringa oleifera leaf ethanolic extract; MOREE1, Moringa oleifera root ethanolic extract 1; MOREE2, Moringa oleifera root ethanolic extract 2, MOFEE1, Moringa oleifera flower ethanolic extract 1; MOFEE2, Moringa oleifera flower ethanolic extract 2; MOBEE, Moringa oleifera bark ethanolic extract; MOSEE1, Moringa oleifera seed ethanolic extract 1; MOSEE2, Moringa oleifera seed ethanolic extract 2. Extracts denoted 1 are Moringa oleifera plants from lowland, and extracts denoted 2 are Moringa oleifera plants from hinterland. 

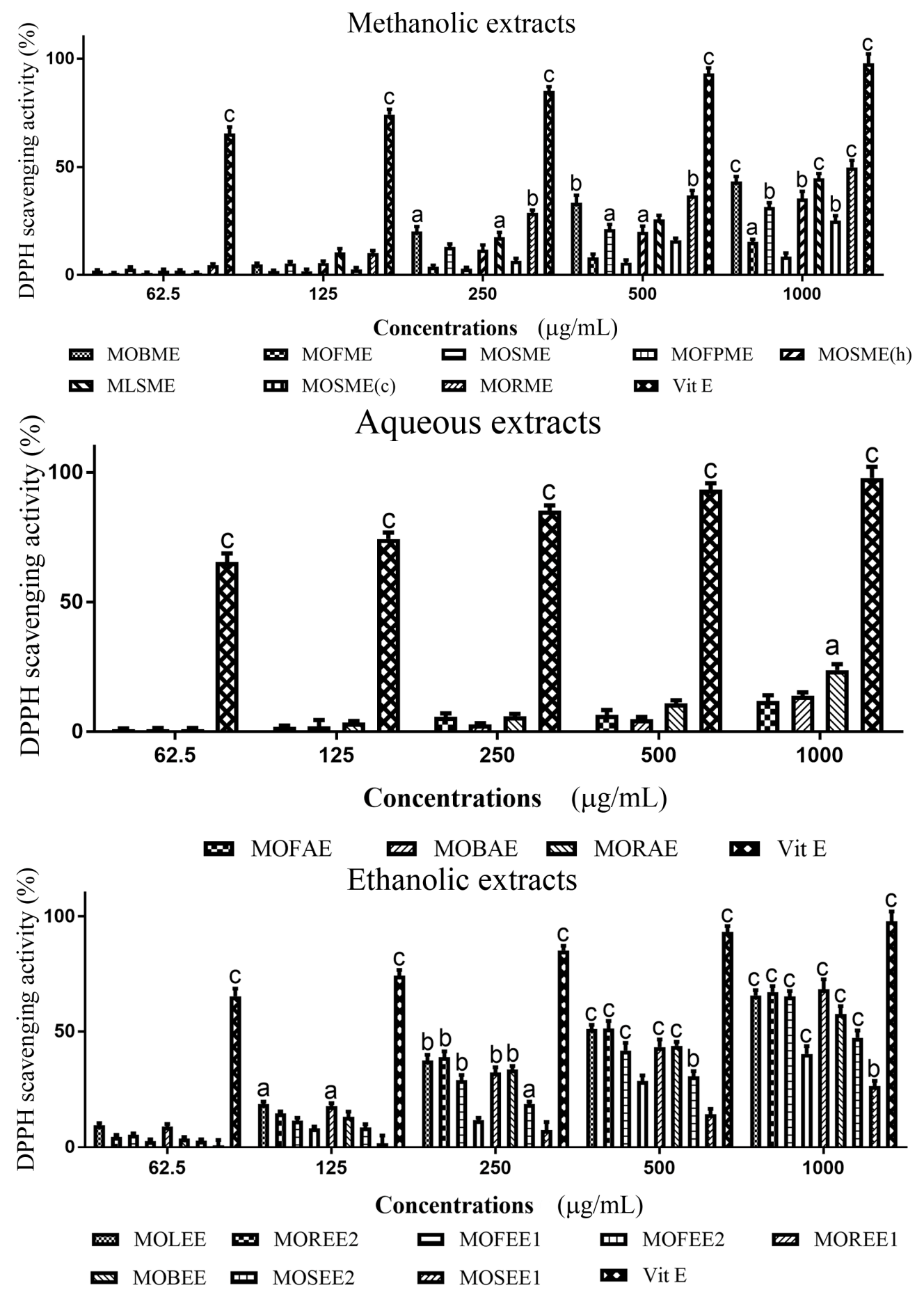

Figure 2. DPPH radical scavenging activity of plant extracts from Moringa oleifera. Plant radical scavenging activity was assessed using a DPPH radical, with results expressed as percentage inhibition. Vitamin $\mathrm{E}$ was used as a positive control. The histograms presented are means $\pm \mathrm{SEM}$ for at least three replicate assays at each extract concentration. a: $p<0.05$. b: $p<0.01$. c: $p<0.001$.

\subsection{Moringa Oleifera Reducing (Antioxidant) Capacity}

Methanolic, aqueous and ethanolic extracts of M. oleifera displayed reducing (antioxidant) capacity in a concentrations dependent manner, although this was generally low relative to ascorbic acid (Figure 3). At an extract concentration of $50 \mu \mathrm{g} / \mathrm{mL}$, of the methanolic extracts, only the MOBME and MORME displayed significant $(p<0.001)$ reducing capacity of $\sim 50 \%$ compared to vitamin $C$ set at 
$100 \%$. Across the eight M. oleifera ethanolic extracts assayed, all except MOSEE2 exhibited significant $(p<0.05-0.001)$ reducing capacity. The highest antioxidant capacity for the ethanolic extracts was $\sim 48 \%$ and $\sim 45 \%$, for MOREE1 and MOREE2, respectively. The order of descending reducing capacity for the M. oleifera methanolic extracts was: MORME $>$ MOBME $>$ MOLSME $>$ MOFME $=$ MOSME $=$ MOFME $>$ MOSME (h) > MOSME (c); and, for the aqueous extracts: MOBAE > MORAE > MOFAE; and ethanolic extracts: MOREE1 > MOREE2 > MOLEE > MOBEE > MOSEE1 > MOFEE1 > MOFEE2 > MOSEE2.
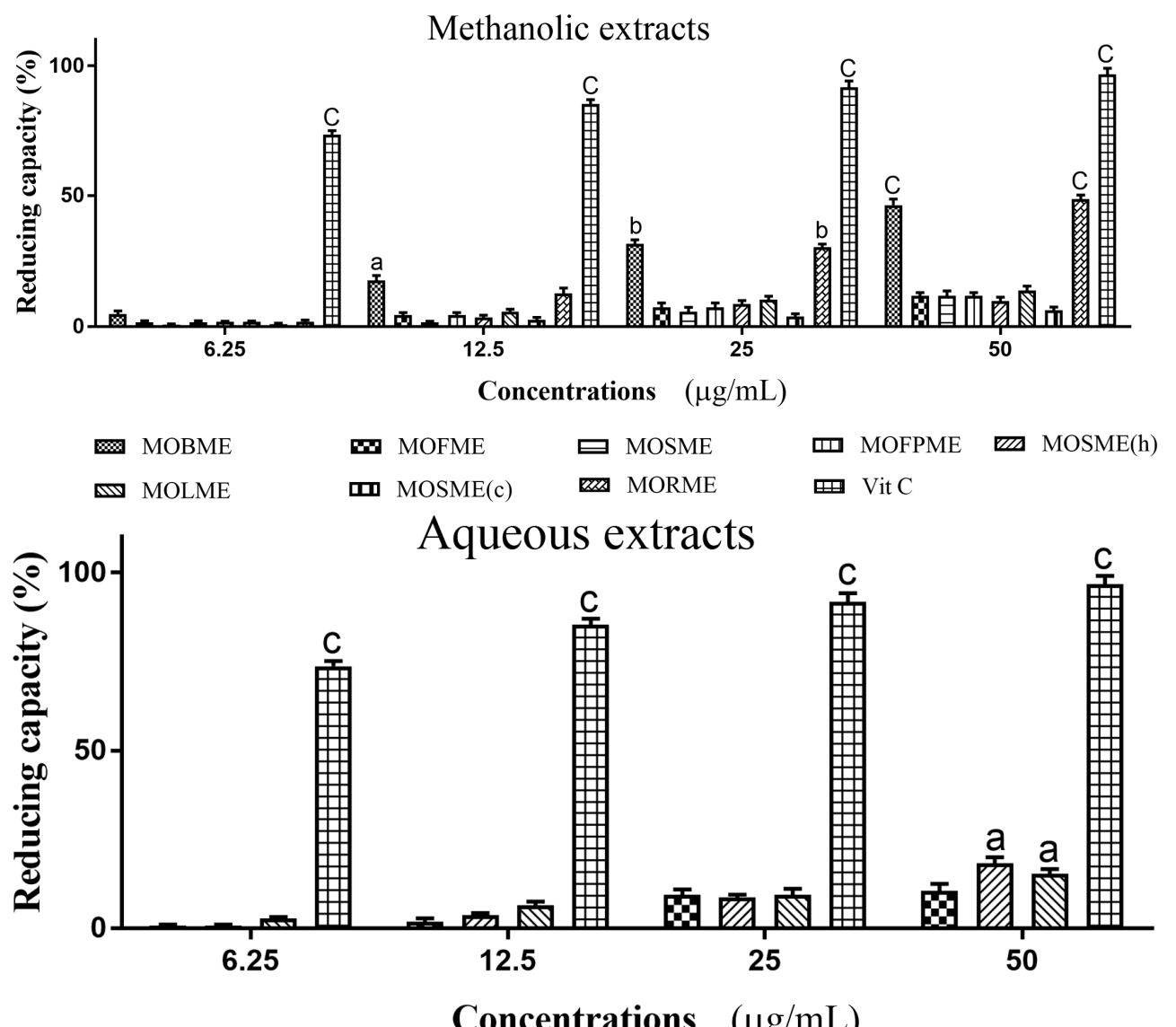

Concentrations $(\mu \mathrm{g} / \mathrm{mL})$

$\boldsymbol{m}$ MOFAE mOBAE MORAE Ethanolic extracts

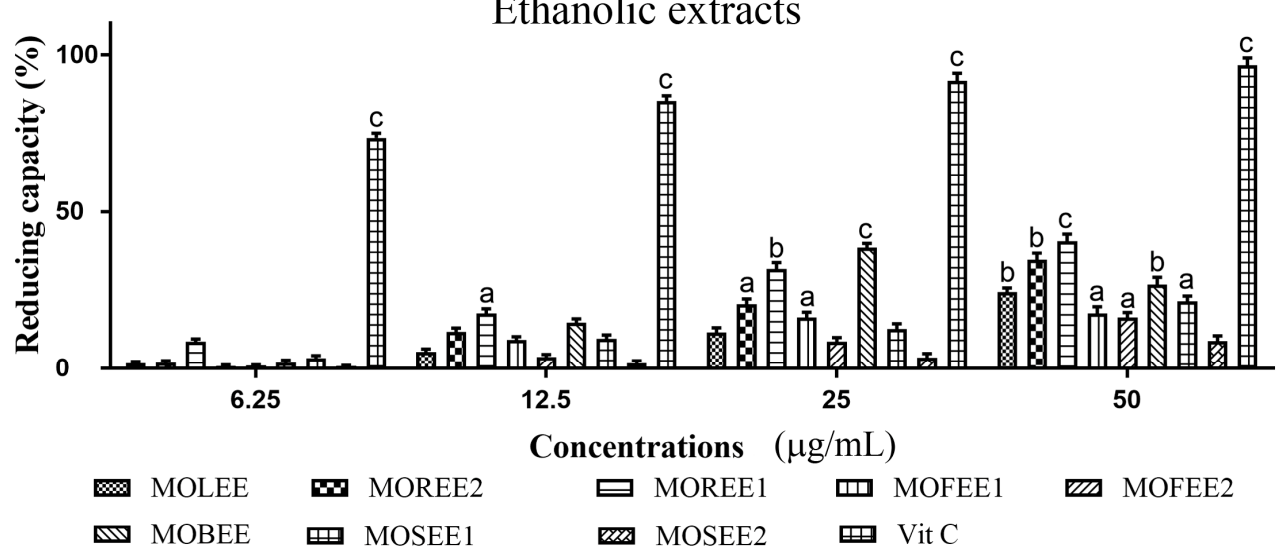

Figure 3. Reductive capacity of plant extracts from Moringa oleifera. Plant reducing power was quantified via the ability (as a percentage) to reduce ferric $\left(\mathrm{Fe}^{3+}\right)$ to ferrous $\left(\mathrm{Fe}^{2+}\right)$ iron. Ascorbic acid (vitamin C) was used as a positive control. The histograms presented are means $\pm \mathrm{SEM}$ for at least three replicate assays at each extract concentration. a: $p<0.05$. b: $p<0.01$. c: $p<0.001$. 


\subsection{Moringa Oleifera Total Phenolic and Total Flavonoid Content}

Total phenolic content (TPC) and total flavonoid content (TFC) of the M. oleifera methanolic, aqueous, and ethanolic extracts were determined (Table 2). All fractions retained phenolic and flavonoid content, with the MORME extract displaying the highest levels of both compounds. Interestingly, there was a significant inverse correlation between total phenolic $(p<0.0001)$ and flavonoid content $(p<0.0012)$, and reduced potency of AChE inhibition (Figure 4). By comparison, there was no correlation between antioxidant capability and inhibition of AChE (Figure 4), or between antioxidant content and either TPC or TFC (results not included).
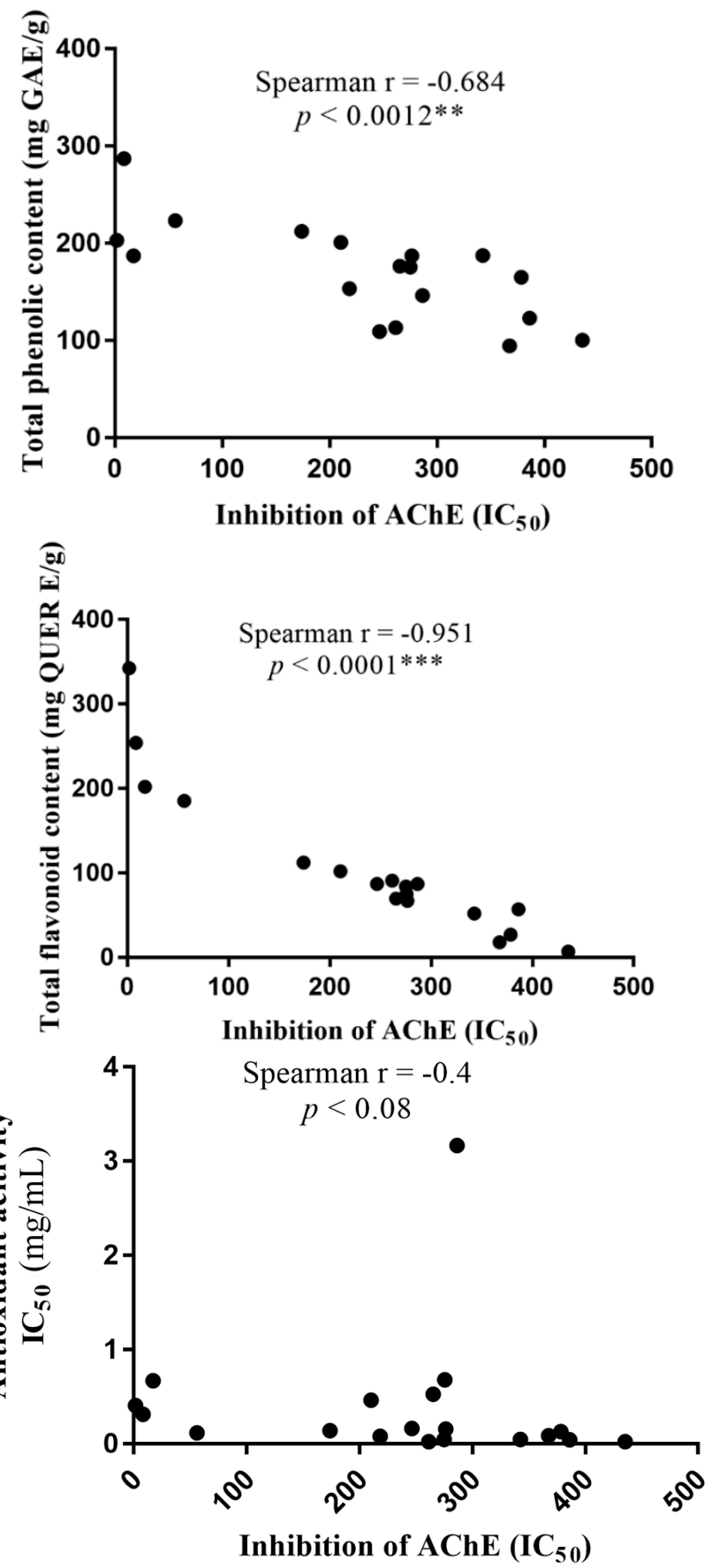

Figure 4. Spearman correlation of AChE inhibitory potency vs total phenolic content, total flavonoid content, and antioxidant potential for plant extracts from Moringa oleifera. Each dot represents one of the methanolic, aqueous, or ethanolic extracts. For significance, ${ }^{* *} p<0.01,{ }^{* * *} p<0.001$. 
Table 2. Total phenolic and flavonoid content of Moringer oleifera methanolic, aqueous, and ethanolic extracts.

\begin{tabular}{|c|c|c|}
\hline Moringa oleifera Extracts & $\begin{array}{c}\text { Total Phenolic Content } \\
\text { (mg GAE/g) }\end{array}$ & $\begin{array}{l}\text { Total Flavonoid Content } \\
\text { (mg QUER E/g) }\end{array}$ \\
\hline \multicolumn{3}{|l|}{ Methanolic } \\
\hline MOBME & $212.3 \pm 2.30$ & $112.5 \pm 2.40$ \\
\hline MOFME & $175.6 \pm 0.09$ & $84.3 \pm 2.30$ \\
\hline MOSME & $187.4 \pm 2.00$ & $52.0 \pm 0.60$ \\
\hline MOFPME & $100.4 \pm 0.08$ & $7.3 \pm 1.90$ \\
\hline $\operatorname{MOSME}(\mathrm{h})$ & $123.2 \pm 1.10$ & $57.0 \pm 3.30$ \\
\hline MOLME & $113.3 \pm 1.90$ & $91.2 \pm 0.90$ \\
\hline MOSME (c) & $94.5 \pm 0.90$ & $18.0 \pm 0.09$ \\
\hline MORME & $287.1 \pm 0.00$ & $254.3 \pm 2.30$ \\
\hline \multicolumn{3}{|l|}{ Aqueous } \\
\hline MOFAE & $165.2 \pm 0.80$ & $27.0 \pm 3.00$ \\
\hline MOBAE & $153.3 \pm 0.08$ & $87.2 \pm 3.60$ \\
\hline MORAE & $187.0 \pm 1.90$ & $67.2 \pm 2.00$ \\
\hline \multicolumn{3}{|l|}{ Ethanolic } \\
\hline MOLEE & $201.0 \pm 2.30$ & $102.2 \pm 1.50$ \\
\hline MOREE2 & $203.2 \pm 0.02$ & $342.5 \pm 1.70$ \\
\hline MOREE1 & $223.2 \pm 1.01$ & $185.4 \pm 2.70$ \\
\hline MOFEE1 & $186.3 \pm 2.00$ & $75.0 \pm 0.30$ \\
\hline MOFEE2 & $176.3 \pm 0.30$ & $69.7 \pm 1.70$ \\
\hline MOBEE & $187.2 \pm 2.00$ & $202.3 \pm 3.10$ \\
\hline MOSEE1 & $146.3 \pm 0.20$ & $95.3 \pm 2.5$ \\
\hline MOSEE2 & $109.2 \pm 0.80$ & $87.2 \pm 3.60$ \\
\hline
\end{tabular}

Extracts denoted 1 are Moringa oleifera plants from lowland, and extracts denoted 2 are Moringa oleifera plants from hinterland.

\section{Discussion}

M. oleifera neuroprotective effects have been reviewed [59-62] and experimentally demonstrated [40,41,63]. Various mechanisms, such as AChE inhibition, modification of monoamine levels, anti-amyloid aggregation, and antioxidant activities are strategies that have been employed for the amelioration of $\mathrm{AD}$ symptoms [60]. Of these, one of the major approaches has involved addressing the levels of acetylcholine in the brain that are depressed in AD using AChE inhibitors $[64,65]$. The cholinesterase inhibitors, eserine, tacrine, donepezil, rivastigamine, and galantamine, are known to have disparaging side effects that include disturbed sleep, diarrhea, nausea, headaches, and seizures [66,67]. As a result, there is intense scientific investigation to screen a plethora of plant extracts to discover more potent $\mathrm{AChE}$ inhibitors, hence this current evaluation of methanolic, aqueous, and ethanolic extracts of various plant parts (leaf, root, bark, flowers, etc.) of M. oleifera for anti-cholinesterase and antioxidant effects.

Many extracts and fractions of different plants, such as Achyrocine tomentosa, Eupatorium viscidum, Ruprechtia apetala, Trichocline reptans, Zanthoxylum coco, Poncirus trifoliate, Treculia obovoidea, Angelica archangelica, Cassia obtisufolia, Salvia officinalis, Desmodium gangeticum, and Carpolobia lutea have been assayed and reported to possess cholinesterase inhibitory activity $[57,60,68]$. However, this is not a universal property of plants per se, thus other plant extracts, for example, from Sideroxylon obtusifolium, Erythrina velutina, Vitex agnus-castus L., Phoradendron piperoides, Chrysobalanus icaco, Bauhinia cheilantha, and Orbignya phalerata do not exhibit any AChE inhibitory activity. Other plants, such as Hyptis fruticosa and Maytenus rigida, possess only low AChE inhibitory effects, whereas the plant investigated herein, M. oleifera, has ethanol leaf extracts with moderate AChE inhibitory activity; while, Vitex agnus-castus L. aqueous extract was an effective inhibitor of AChE [68].

A methanolic extract of M. oleifera with anti-cholinesterase effects has also been reported in vitro and in vivo in zebrafish (Danio rerio) [69], however, Moringa flower extract had no effect on gut AChE 
activity of insect larvae of Aedes aegypti [70]. Our explorative screening study revealed that M. oleifera methanolic, aqueous, and ethanolic extracts demonstrated considerable AChE inhibitory activity, that for some fractions was comparable to that induced with eserine. The MORME and MOBME from the methanolic extracts were the most potent $\mathrm{AChE}$ inhibitors with $\mathrm{IC}_{50}$ values of 0.00845 and $1.740 \mu \mathrm{g} / \mathrm{mL}$, respectively. The MOBAE and MORAE from the M. oleifera aqueous extracts were the most potent, but had high $\mathrm{IC}_{50}$ values of 0.2764 and $0.215 \mu \mathrm{g} / \mathrm{mL}$, respectively. Whereas the MOREE2, MOBEE and MOREE1 of the M. oleifera ethanolic extracts with $\mathrm{IC}_{50}$ values of $0.0173,0.0563$ and $0.00175 \mu \mathrm{g} / \mathrm{mL}$, respectively, were the most potent ethanolic extracts.

Eserine (physostigmine) at a concentration of $0.02 \mu \mathrm{g} / \mathrm{mL}(\sim 72 \mathrm{nM})$ was used as a positive control to completely inhibit electric eel or rat brain AChE, and for which relative inhibition of AChE by plant extracts was gauged. At this eserine concentration human brain AChE would likewise be inhibited $\sim 100 \%$ ( $\mathrm{IC}_{50}$ of $\sim 14 \mathrm{nM}$ ) [57,71,72]. Hence, across the 19 screened M. oleifera extracts MOREE1, MORME, MOREE2 and MOBEE stand out as the majorly active AChE inhibitors with $\mathrm{IC}_{50}$ values of 0.00175 , $0.00845,0.0173$ and $0.0563 \mu \mathrm{g} / \mathrm{mL}$, respectively. These fractions show particular promise for further development and purification since in their partially purified form, they were more potent $\mathrm{AChE}$ inhibitors than eserine.

To combat the multifaceted nature of neurodegenerative diseases such as $\mathrm{AD}$, additional off-target actions such as radical scavenging and reducing (antioxidant) activities would be of benefit. Our results show that M. oleifera extracts, MOBME, MOLSME, MORME, MOLEE, MOFEE2, MOREE2 and MOREE1 significantly reduced DPPH radicals to about $50 \%$ of those of pure antioxidant Vitamin E. Superoxide anion radical $\left(\mathrm{O}^{2-}\right)$ is a precursor to active free radicals that have the potential of reacting with biological macromolecules, and thereby inducing tissue damage [14]. In the assay undertaken, antioxidants react with DPPH, a purple colored stable free radical and convert it into a colorless $\alpha$ - $\alpha$-diphenyl- $\beta$-picryl hydrazine. Plants with antioxidant properties, on interaction with DPPH, either transfer an electron or hydrogen atom to DPPH, thus neutralizing its free radical character, and changing the solution colour from purple to yellow. Our results that M. oleifera extracts displayed antioxidant properties was also validated by the ability to reduce ferric to ferrous iron. Mild, but useful reducing (antioxidant) capacity was apparent, in keeping with other studies that have quantified M. oleifera antioxidant capability [52-54].

In addition to establishing the potent $\mathrm{AChE}$ inhibitory activity and antioxidant properties of M. oleifera we quantified the total phenolic and total flavonoid contents. For the MORME extracts, a relatively high phenolic and flavonoid content was detected. M. oleifera extracts that demonstrated potent AChE inhibitory activity, also displayed significant antioxidant activities and contained a relatively high content of polyphenols and flavonoids. The natural antioxidants that are present in plants, such as M. oleifera, may inhibit or prevent the deleterious consequences of oxidative stress, and this could relate to certain phenolic and flavonoid contents [46]. For example, polyphenols inhibit lipid peroxidation by acting as chain-breaking peroxyl-radical scavengers [73]. For M. oleifera, certain terpenoids, steroids, and phenolic compounds such as tannins, coumarins and flavonoids could provide the proficient antioxidant properties [74,75].

Interestingly, the $\mathrm{AChE} \mathrm{IC} \mathrm{C}_{50}$ inhibitory concentrations for $M$. oleifera extracts were significantly inversely correlated to total phenolic and total flavonoid contents (Figure 4). This suggests that the agent(s) responsible for the AChE inhibitory activity contain phenolic and flavonoid compounds. However, there was not a correlation between AChE inhibitory activity and antioxidant activity, or between antioxidant activity and TPC or TFC. Polyphenols may certainly possess antioxidant properties [76,77], but the antioxidant activities of flavonoids are variable, and may, for example, reflect the presence or absence of a catechol B-ring [78]. Hence, the discordance between TPC/TFC and antioxidant activity may simply reflect the specific phenolic or flavonoid compound components of $M$. oleifera that were retained while using our solvent systems. We employed methanol, ethanol, and water for extract dissolution based upon their extensive use as solvents in ethnomedicine $[79,80]$, 
as they are relatively inexpensive, suitable for dissolution of both polar and non-polar compounds, and can be evaporated with ease facilitating extract concentration.

Collectively, the extensive armamentarium of phytochemicals of M. oleifera [45-47] likely contribute to the potent anti-cholinesterase and antioxidant effects we describe in this study. However, a limitation of our results is that the data only reflects an in vitro study. To date, preliminary in vivo findings have shown that a M. oleifera hydroalcohol leaf extract was capable of mitigating memory impairment in rats [40]. Yet follow-up studies that assess the ability of other M. oleifera extracts or purified compounds to ameliorate symptoms of cholinergic deficits in animal models of diseases such as AD, Parkinson's disease, or myasthenia gravis are still required. Nevertheless, the impetus for in vivo studies should be based upon satisfactory in vitro data of potent anti-cholinesterase activity, and our study certainly suggests that $M$. oleifera reaches this criterion.

Author Contributions: L.L.N and E.E conceived and designed the experiments; L.L.N. wrote the paper; L.L.N. and E.E. performed the experiments; E.E. and W.G.C. analyzed and interpreted the data; W.G.C. critically reviewed the manuscript; J.S.A. and I.S provided the aqueous and ethanolic extract of Moringa oleifera.

Funding: The research work was partly funded by the University of Nottingham through International Travelling awards to L.L.N. and E.E. while W.G.C hosted L.L.N and E.E with support from the University of Nottingham.

Acknowledgments: The authors are thankful to International Visiting Fellowship grants, funded by the University of Nottingham to W.G.C. to support L.L.N. and E.E.

Conflicts of Interest: The authors can endorse that there are no conflicts of interest related with the publication of this manuscript. The funding sponsors had no role in the design of the study; in the collection, analyses, or interpretation of data; in the writing of the manuscript; or in the decision to publish the results.

\section{References}

1. Rouch, I.; Dorey, J.-M.; Boublay, N.; Henaff, M.-A.; Dibie-Racoupeau, F.; Makaroff, Z.; Haston, S.; Benoit, M.; Barrellon, M.; Fedrico, D.; et al. Personality, Alzheimer's disease and behavioural and cognitive symptoms of dementia: The PACO prospective cohort study protocol. BMC Geriatr. 2014, 14, 1-10. [CrossRef] [PubMed]

2. World Health Organization (WHO). Dementia; Fact Sheet 362; World Health Organization (WHO): Geneva, Switzerland, 2015.

3. Alzheimer's Disease International, World Alzheimer's Report 2015: Global Impact of Dementia, 2015. Available online: http:/ / www.alz.co.uk/research/world-report-2015 (accessed on 4 October 2016).

4. Alzheimer's Association. 2016 Alzheimer's disease facts and figures. Alzheimers Dement. 2016, 12, 459-509.

5. Borsje, P.; Hems, M.A.; Lucassen, P.L.; Bor, H.; Koopmans, R.T.; Pot, A.M. Psychological distress in informal caregivers of patients with dementia in primary care: Course and determinants. Fam. Pract. 2016, 33, 374-381. [CrossRef] [PubMed]

6. Serrano-Pozo, A.; Frosch, M.P.; Masliah, E.; Hyman, B.T. Neuropathological Alterations in Alzheimer Disease. Cold Spring Harbor Perspect. Med. 2011, 1, a006189.

7. Uddin, M.S.; Stachowiak, A.; Mamun, A.A.; Tzvetkov, N.T.; Takeda, S.; Atanasov, A.G.; Bergantin, L.B.; Abdel-Daim, M.M.; Stankiewicz, A.M. Autophagy and Alzheimer's disease: From Molecular Mechanisms to Therapeutic Implications. Front. Aging Neurosci. 2018, 10. [CrossRef]

8. Irvine, G.B.; El-Agnaf, O.M.; Shankar, G.M.; Walsh, D.M. Protein aggregation in the brain: The molecular basis for Alzheimer's and Parkinson's diseases. Mol. Med. 2008, 14, 451-464. [CrossRef] [PubMed]

9. Bloom, G.S. Amyloid-beta and tau: The trigger and bullet in Alzheimer disease pathogenesis. JAMA Neurol. 2014, 71, 505-508. [CrossRef] [PubMed]

10. Nowacek, A.; Kosloski, L.M.; Gendelman, H.E. Neurodegenerative disorders and nanoformulated drug development. Nanomedicine 2009, 4, 541-555. [CrossRef] [PubMed]

11. Ballard, C.; Gauthier, S.; Corbett, A.; Brayne, C.; Aarsland, D.; Jones, E. Alzheimer's disease. Lancet 2011, 377 , 1019-1031. [CrossRef]

12. Moreira, P.I.; Smith, M.A.; Zhu, X.; Nunomura, A.; Castellani, R.J.; Perry, G. Oxidative stress and neurodegeneration. Ann. N. Y. Acad. Sci. 2005, 1043, 545-552. [CrossRef] [PubMed]

13. Zhang, F.; Jiang, L. Neuroinflammation in Alzheimer's disease. Neuropsychiatr. Dis. Treat. 2015, 11, $243-256$. [CrossRef] [PubMed] 
14. Mancuso, C.; Scapagini, G.; Curro, D.; Giuffrida, S.A.M.; DeMarco, C.; Butterfield, D.A.; Calabrese, V. Mitochondrial dysfunction, free radical generation and cellular stress response in neurodegenerative disorders. Front. Biosci. 2007, 12, 1107-1123. [CrossRef] [PubMed]

15. Mufson, E.J.; Counts, S.E.; Perez, S.E.; Ginsberg, S.D. Cholinergic system during the progression of Alzheimer's disease: Therapeutic implications. Expert Rev. Neurother. 2008, 8, 1703-1718. [CrossRef] [PubMed]

16. Nunomura, A.; Perry, G.; Aliev, G.; Hirai, K.; Takeda, A.; Balraj, E.K.; Jones, P.K.; Ghanbari, H.; Wataya, H.; Shimohama, S.; et al. Oxidative damage is the earliest event in Alzheimer disease. J. Neuropathol. Exp. Neurol. 2001, 60, 759-767. [CrossRef] [PubMed]

17. Lovell, M.A.; Markesbery, W.R. Oxidative DNA Damage in Mild Cognitive Impairment and Late-Stage Alzheimer's Disease. Nucleic Acids Res. 2007, 35, 7497-7504. [CrossRef] [PubMed]

18. Li, S.; Chenm, G.; Zhang, C.; Wu, M.; Wu, S.; Liu, Q. Research progress of natural antioxidants in foods for the treatment of diseases. Food Sci. Hum. Wellness 2014, 3, 110-116. [CrossRef]

19. Hossain, M.B.; Brunton, N.P.; Barry-Ryan, C.; Martin-Diana, A.B.; Wilkinson, M. Antioxidant activity of spices extracts and phenolics in comparison to synthetic antioxidants. Rasayan J. Chem. 2008, 4, 751-756.

20. Satyanarayana, U.; Kumar, A.N.; Naidu, J.N.; Prasad, D.K.V. Antioxidant Supplementation for Health-A Boon or a Bane? J. Dr. NTR Univ. Health Sci. 2014, 3, 221-230. [CrossRef]

21. Pham-Huy, L.A.; He, H.; Pham-Huy, C. Free Radicals, Antioxidants in Disease and Health. Int. J. Biomed. Sci. 2008, 4, 89-96. [PubMed]

22. Perry, E.K.; Pickering, A.T.; Wang, W.W.; Houghton, P.J.; Perry, N.S. Medicinal plants and Alzheimer's disease: From ethno botany to phytotherapy. J. Pharm. Pharmacol. 1999, 51, 527-534. [CrossRef] [PubMed]

23. Uddin, M.S.; Mamun, A.A.; Iqbal, M.A.; Islam, A.; Hossain, M.F.; Khanum, S.; Rashid, M. Analyzing Nootropic Effect of Phyllanthus reticulatus Poir. on Cognitive Functions, Brain Antioxidant Enzymes and Acetylcholinesterase Activity against Aluminium-Induced Alzheimer's Model in Rats: Applicable for Controlling the Risk Factors of Alzheimer's Disease. Adv. Alzh Dis. 2016, 5, 87-102.

24. Chen, L.-E.; Wu, F.; Zhao, A.; Ge, H.; Zhan, H. Protection Efficacy of the Extract of Ginkgo biloba against the Learning and Memory Damage of Rats under Repeated High Sustained $+\mathrm{Gz}$ Exposure. Evid-Based Complement. Altern. Med. 2016. [CrossRef]

25. Aguiar, S.; Borowski, T. Neuropharmacological Review of the Nootropic Herb Bacopa monnieri. Rejuv. Res. 2013, 16, 313-326. [CrossRef] [PubMed]

26. Singhal, A.K.; Naithani, V.; Bangar, O.P. Medicinal Plants with a Potential to Treat Alzheimer and Associated Symptoms. Int. J. Nutr. Pharmacol. Neurol. Dis. 2012, 2, 84-91. [CrossRef]

27. Ramachandran, C.; Peter, K.V.; Gopalakrishnan, P.K. Drumstick (Moringa oleifera): A multipurpose Indian vegetable. Econ. Bot. 1980, 34, 276-283. [CrossRef]

28. Nadkarni, A.K. Indian Materia Medica; Popular Prakashan: Bombay, India, 1976; pp. 810-816.

29. Anwar, F.; Latif, S.; Ashraf, M.; Gilani, A.H. Moringa oleifera: A food plant with multiple medicinal uses. Phytother. Res. 2007, 21, 17-25. [CrossRef] [PubMed]

30. Mokkhasmit, M.; Swasdimongkol, K.; Ngarmwathana, W.; Permphiphat, U. Pharmacological evaluation of Thai medicinal plants. J. Med. Assoc. Thailand 1971, 54, 490-504.

31. Kooltheat, N.; Sranujit, R.P.; Chumark, P.; Potup, P.; Laytragoon-Lewin, N.; Usuwanthim, K. An ethyl acetate fraction of Moringa oleifera Lam. inhibits human macrophage cytokine production induced by cigarette smoke. Nutrients 2014, 6, 697-710. [CrossRef] [PubMed]

32. Fard, M.T.; Arulselvan, P.; Karthivashan, G.; Adam, S.K.; Fakurazi, S. Bioactive extract from Moringa oleifera inhibits the pro-inflammatory mediators in lipopolysaccharide stimulated macrophages. Pharmacogn. Mag. 2015, 11, S556-S563. [PubMed]

33. Arulselvan, P.; Tan, W.S.; Gothai, S.; Muniandy, K.; Fakurazi, S.; Esa, N.M.; Alarfaj, A.A.; Kumar, S.S. Anti-inflammatory potential of ethyl acetate fraction of Moringa oleifera in downregulating the NF-kappaB signaling pathway in lipopolysaccharide-stimulated macrophages. Molecules 2016, 21, 1452. [CrossRef] [PubMed]

34. Giacoppo, S.; Rajan, T.S.; De Nicola, G.R.; Iori, R.; Rollin, P.; Bramanti, P.; Mazzon, E. The isothiocyanate isolated from Moringa oleifera shows potent anti-inflammatory activity in the treatment of murine subacute Parkinson's disease. Rejuv. Res. 2017, 20, 50-63. [CrossRef] [PubMed] 
35. Peixoto, J.R.; Silva, G.C.; Costa, R.A.; de Sousa, F.J.; Vieira, G.H.; Filho, A.A.; Dos, F.V.R. In vitro antibacterial effect of aqueous and ethanolic Moringa leaf extracts. Asian Pac. J. Trop. Med. 2011, 4, 201-204. [CrossRef]

36. Chumark, P.; Khunawat, P.; Sanvarinda, Y.; Phornchirasilp, S.; Morales, N.P.; Phivthong-Ngam, L.; Ratanachamnong, P.; Srisawat, S.; Pongrapeeporn, K.U. The in vitro and ex vivo antioxidant properties, hypolipidaemic and antiatherosclerotic activities of water extract of Moringa oleifera Lam. leaves. J. Ethnopharmacol. 2008, 116, 439-446. [CrossRef] [PubMed]

37. Al-Asmari, A.K.; Albalawi, S.M.; Athar, M.T.; Khan, A.Q.; Al-Shahrani, H.; Islam, M. Moringa oleifera as an anti-cancer agent against breast and colorectal cancer cell lines. PLoS ONE 2015, 10, e0135814. [CrossRef] [PubMed]

38. Sharifudin, S.A.; Fakurazi, S.; Hidayat, M.T.; Hairuszah, I.; Moklas, M.A.; Arulselvan, P. Therapeutic potential of Moringa oleifera extracts against acetaminophen-induced hepatotoxicity in rats. Pharm. Biol. 2013, 51, 279-288. [CrossRef] [PubMed]

39. Singh, D.; Arya, P.V.; Aggarwal, V.P.; Gupta, R.S. Evaluation of antioxidant and hepatoprotective activities of Moringa oleifera Lam. leaves in carbon tetrachloride-intoxicated rats. Antioxidants (Basel) 2014, 3, 569-591. [CrossRef] [PubMed]

40. Sutalangka, C.; Wattanathorn, J.; Muchimapura, S.; Thukham-mee, W. Moringa oleifera mitigates memory impairment and neurodegeneration in animal model of age-related dementia. Oxid. Med. Cell. Longev. 2013, 2013. [CrossRef] [PubMed]

41. Hannan, M.A.; Kang, J.Y.; Mohibbullah, M.; Hong, Y.K.; Lee, H.; Choi, J.S.; Choi, I.S.; Moon, I.S. Moringa oleifera with promising neuronal survival and neurite outgrowth promoting potentials. J. Ethnopharmacol. 2014, 152, 142-150. [CrossRef] [PubMed]

42. Ekong, M.B.; Ekpo, M.M.; Akpanyung, E.O.; Nwaokonko, D.U. Neuroprotective effect of Moringa oleifera leaf extract on aluminium-induced temporal cortical degeneration. Metab. Brain Dis. 2017, 32, 1437-1447. [CrossRef] [PubMed]

43. Mehta, L.K.; Balaraman, R.; Amin, A.H.; Bafna, P.A.; Gulati, O.D. Effects of fruits of Moringa oleifera on the lipid profile of normal and hypercholesterolemic rabbits. J. Ethnopharmacol. 2003, 86, 191-195. [CrossRef]

44. Ezeamuzle, I.C.; Ambadederomo, A.W.; Shode, F.O.; Ekwebelem, S.C. Antiinflammatory effects of Moringa oleifera root extract. Int. J. Pharmacogn. 1996, 34, 207-212. [CrossRef]

45. Atawodi, S.E.; Atawodi, J.C.; Idakwo, G.A.; Pfundstein, B. Evaluation of the polyphenol content and antioxidant properties of methanol extracts of the leaves, stem, and root barks of Moringa oleifera Lam. J. Med. Food 2010, 13, 710-716. [CrossRef] [PubMed]

46. Siddhuraju, P.; Becker, K. Antioxidant properties of various solvent extracts of total phenolic constituents from three different agroclimatic origins of drumstick tree (Moringa oleifera Lam.) leaves. J. Agric. Food Chem. 2003, 51, 2144-2155. [CrossRef] [PubMed]

47. Mensah, J.K.; Ikhajiagbe, B.; Edema, N.E.; Emokhor, J. Phytochemical, nutritional and antibacterial properties of dried leaf powder of Moringa oleifera (Lam.) from Edo Central Province, Nigeria. J. Nat. Prod. Plant Resour. 2012, 2, 107-112.

48. Omodanisi, E.; Aboua, Y.G.; Oguntibeju, O.O. Assessment of the Anti-Hyperglycaemic, Anti-Inflammatory and Antioxidant Activities of the Methanol Extract of Moringa oleifera in Diabetes-Induced Nephrotoxic Male Wistar Rats. Molecules 2017, 22, 439. [CrossRef] [PubMed]

49. Verma, S.C.; Bannerji, R.; Mirra, G.; Nigam, S.K. Nutritional value of Moringa. Curr. Sci. 1976, 45, 769-771.

50. Goyal, B.R.; Agrawal, B.B.; Goyal, R.K.; Mehta, A.A. Phyto-pharmacology of Moringa oleifera Lam. 6 An overview. Nat. Prod. Radiance 2007, 6, 347-353.

51. Adedapo, A.A.; Mogbojuri, O.M.; Emikpe, B.O. Safety evaluations of the aqueous extract of the leaves of Moringa oleifera in rats. J. Med. Plants Res. 2009, 3, 586-591.

52. Wright, R.J.; Lee, K.S.; Hyacinth, H.I.; Hibbert, J.M.; Reid, M.E.; Wheatley, A.O.; Asemota, H.N. An investigation of the Antioxidant Capacity in Extracts from Moringa oleifera Plants Grown in Jamaica. Plant 2017, 6, 48. [CrossRef] [PubMed]

53. Iqbal, S.; Bhanger, M.I. Effect of season and production location on antioxidant activity of Moringa oleifera leaves grown in Pakistan. J. Food Compos. Anal. 2006, 19, 544-551. [CrossRef]

54. Sreelatha, S.; Padma, P.R. Antioxidant Activity and Total Phenolic Content of Moringa oleifera Leaves in Two Stages of Maturity. Plant Foods Hum. Nutr. 2009, 64, 303-311. [CrossRef] [PubMed] 
55. Carter, W.G.; Tarhoni, M.; Rathbone, A.J.; Ray, D.E. Differential protein adduction by seven organophosphorus pesticides in both brain and thymus. Hum. Exp. Toxicol. 2007, 26, 347-353. [CrossRef] [PubMed]

56. Tarhoni, M.H.; Vigneswara, V.; Smith, M.; Anderson, S.; Wigmore, P.; Lees, J.; Ray, D.E.; Carter, W.G. Detection, quantification, and microlocalisation of targets of pesticides using microchannel plate autoradiographic imagers. Molecules 2011, 16, 8535-8551. [CrossRef] [PubMed]

57. Nwidu, L.L.; Elmorsy, E.; Thornton, J.; Wijamunige, B.; Wijesekara, A.; Tarbox, R.; Warren, A.; Carter, W.G. Antiacetylcholinesterase activity and antioxidant properties of extracts and fractions of Carpolobia lutea. Pharm. Biol. 2017, 55, 1875-1883. [CrossRef] [PubMed]

58. Ellman, G.L.; Courtney, K.D.; Andres, V.; Featherstone, R.M. A new and rapid colorimetric determination of acetylcholinesterase activity. Biochem. Pharmacol. 1961, 7, 88-95. [CrossRef]

59. Ganguly, R.; Guha, D. Alteration of brain monoamines \& EEG wave pattern in rat model of Alzheimer's disease \& protection by Moringa oleifera. Indian J. Med. Res. 2008, 128, 744-751.

60. Obulesu, M.; Rao, D.M. Effect of plant extracts on Alzheimer's disease: An insight into therapeutic avenues. J. Neurosci. Rural Pract. 2011, 2, 56-61. [CrossRef] [PubMed]

61. Igado, O.O.; Olopade, J.O. A Review on the Possible Neuroprotective Effects of Moringa oleifera Leaf Extract. Niger J. Physiol. Sci. 2017, 31, 183-187. [PubMed]

62. Kou, X.; Li, B.; Olayanju, J.B.; Drake, J.M.; Chen, N. Nutraceutical or Pharmacological Potential of Moringa oleifera Lam. Nutrients 2018, 10, 343. [CrossRef] [PubMed]

63. Kirisattayakul, W.; Wattanathorn, J.; Tong-Un, T.; Muchimapura, S.; Wannanon, P.; Jittiwat, J. Cerebroprotective effect of Moringa oleifera against focal ischemic stroke induced by middle cerebral artery occlusion. Oxid. Med. Cell. Longev. 2013, 2013, 1-10. [CrossRef] [PubMed]

64. Mark, H.; Cornelius, K. Use of Cholinesterase inhibitors in Dementia. Adv. Psychiatr. Treat. 2002, 8, 89-96.

65. Nair, V.; Priya Jennifer, M.H. Anticholinesterases and anticholinergic drugs. Oxford J. 2004, 4, $164-168$. [CrossRef]

66. Rogers, S.L.; Farlow, M.R.; Doody, R.S.; Mohs, R.; Friedhoff, L.T.; Donepezil Sudy Group. A 24-week, double blind, placebo-controlled trial of donepezil in patients with Alzheimer's disease. Neurology 1998, 50, 136-145. [CrossRef] [PubMed]

67. Mehta, M.; Abdu, A.; Marwan, S. New Acetylcholinesterase Inhibitors for Alzheimer's Disease. Intern. J. Alzheimer Dis. 2012. [CrossRef] [PubMed]

68. Mota, W.M.; Barros, M.L.; Cunha, P.E.L.; Santana, M.V.A.; Stevam, C.S.; Leopoldo, P.T.G.; Fernandes, R.P.M. Evaluation of acetylcholinesterase inhibition by extracts from medicinal plants. Rev. Bras. Plant. Med. 2012, 14, 624-628. [CrossRef]

69. Sharayu, R.; Asmita, M. Screening of acetylcholinestereases inhibitors by Moringa oleifera. Int. J. Life Sci. 2016, 4, 302-305.

70. Pontual, E.V.; Napoleao, T.H.; Dias de Assis, C.R.; Bezerra, R.S.; Xavier, H.S.; Navarro, D.M.; Coelho, L.C.; Paiva, P.M. Effect of Moringa oleifera flower extract or larval trypsin and acetylcholinesterase activities in Aedes aegypti. Arch. Insect Biochem. Physiol. 2012, 79, 135-152. [CrossRef] [PubMed]

71. Thomsen, T.; Kaden, B.; Fischer, J.P.; Bickel, U.; Barz, H.; Gusztony, G.; Cervos-Navarro, J.; Kewitz, H. Inhibition of acetylcholinesterase activity in human brain tissue and erythrocytes by galanthamine, physostigmine and tacrine. Eur. J. Clin. Chem. Clin. Biochem. 1991, 29, 487-492. [CrossRef] [PubMed]

72. Triggle, D.J.; Mitchell, J.M.; Filler, R. The pharmacology of physostigmine. CNS Drug Rev. 1998, 4, 87-136. [CrossRef]

73. Salah, N.; Miller, N.J.; Paganga, G.; Tijburg, L.; Bolwell, G.P.; Rice-Evans, C. Polyphenolic flavanols as scavengers of aqueous phase radicals and as chain-breaking antioxidants. Arch. Biochem. Biophys. 1995, 322, 339-346. [CrossRef] [PubMed]

74. Brilhante, R.S.N.; Jamille Sales, J.A.; Pereira, V.S.; Castelo-Branco, D.S.C.M.; Cordeiro, R.A.; Sampaio, C.M.S.; Paiva, M.A.N.; dos Santos, J.B.F.; Sidrim, J.J.C.; Rocha, M.F.G. Research advances on the multiple uses of Moringa oleifera: A sustainable alternative for socially neglected population. Asian Pac. J. Trop. Med. 2017, 10, 621-630. [CrossRef] [PubMed]

75. Alhakmani, F.; Kumar, S.; Khan, S.A. Estimation of total phenolic content, in-vitro antioxidant and anti-inflammatory activity of flowers of Moringa oleifera. Asian Pac. J. Trop. Biomed. 2013, 3, 623-627. [CrossRef] 
76. Rice-Evans, C.; Miller, N.; Paganga, G. Antioxidant properties of phenolic compounds. Trends Plant Sci. 1997, 2, 152-159. [CrossRef]

77. Fauconneau, B.; Waffo-Teguo, P.; Huguet, F.; Barrier, L.; Decendit, A.; Merillon, J.M. Comparative study of radical scavenger and antioxidant properties of phenolic compounds from Vitis vinifera cell cultures using in vitro tests. Life Sci. 1997, 61, 2103-2110. [CrossRef]

78. Lu, Y.; Foo, L.Y. Antioxidant activities of polyphenols from sage (Salvia officinalis). Food Chem. 2001, 75, 197-202. [CrossRef]

79. Eloff, N.J. Which extractant should be used for the screening and isolation of antimicrobial components from plants? J. Ethnopharmacol. 1998, 60, 1-8. [CrossRef]

80. Azmir, J.; Zaidul, I.S.M.; Rahman, M.M.; Sharif, K.M.; Mohamed, A.; Sahena, F.; Jahurul, M.H.A.; Ghafoor, K.; Norulaini, N.A.N.; Omar, A.K.M. Techniques for extraction of bioactive compounds from plant materials: A review. J. Food Eng. 2013, 117, 426-436. [CrossRef]

(C) 2018 by the authors. Licensee MDPI, Basel, Switzerland. This article is an open access article distributed under the terms and conditions of the Creative Commons Attribution (CC BY) license (http:/ / creativecommons.org/licenses/by/4.0/). 